\title{
On Yanomami ceremonial dialogues: a political aesthetic of metaphorical agency
}

Sobre los diálogos ceremoniales Yanomami: una estética política de eficiacia metafórica

Sur les dialogues cérémoniaux yanomami : une esthétique politique de l'efficacité métaphorique

José Antonio Kelly Luciani

\section{OpenEdition}

\section{Journals}

Electronic version

URL: https://journals.openedition.org/jsa/14892

DOI: 10.4000/jsa. 14892

ISSN: $1957-7842$

\section{Publisher}

Société des américanistes

Printed version

Date of publication: 15 June 2017

Number of pages: 179-214

ISSN: 0037-9174

\section{Electronic reference}

José Antonio Kelly Luciani, "On Yanomami ceremonial dialogues: a political aesthetic of metaphorical agency", Journal de la Société des américanistes [Online], 103-1 | 2017, Online since 15 June 2017, connection on 02 September 2022. URL: http://journals.openedition.org/jsa/14892 ; DOI: https:// doi.org/10.4000/jsa. 14892 


\title{
On Yanomami ceremonial dialogues: a political aesthetic of metaphorical agency
}

\author{
José Antonio KeLly LuCiANI *
}

The Yanomami ceremonial dialogues (wayamou) are a ritualized form of verbal exchange aimed at inter-community conflict resolution. This paper is devoted to describing and analyzing these ceremonial dialogues, taking a closer look at a. the significance of their tropic nature; $b$. the role played by knowledge acquired in dreams; and c. the manner in which « naming » the forest socializes space, peopling it not only with communities, but also with resources and exchange possibilities. I shall demonstrate that this combination of features delineates a political aesthetics reminiscent of shamanic form and efficacy. Such proximity suggests lines of continuity between political and religious agency, helping to bridge the gap Amazonianist anthropology has carved between the analysis of intra-human politics and that between humans and non-humans. [Key words: ceremonial dialogues, Yanomami, metaphor, Amerindian politics, agency.]

Sobre los diálogos ceremoniales Yanomami: una estética política de eficiacia metafórica. Los diálogos ceremoniales yanomami (wayamou) son una forma ritualizada de intercambio verbal orientada a la resolución de conflictos intercomunitarios. Este trabajo describe y analiza estos diálogos enfocándose en a. el significado de su carácter metafórico; b. el papel del conocimiento adquirido en sueños; y c. la forma en que el nombramiento del territorio socializa el espacio, poblándolo no solo de comunidades, sino también con sus recursos y posibilidades de intercambio. Trataré de demostrar que esta combinación de características nos coloca frente una estética política propia del chamanismo. Esta proximidad sugiere una continuidad entre tipos de agencia politíca y religiosa que puede ayudar a acortar la distancia que la antropología amazonista ha creado entre el análisis de la politica intra-humana y aquella que se lleva a cabo entre humanos y no-humanos. [Palabras clave: diálogos ceremoniales, Yanomami, metáfora, política amerindia, agencia.]

Sur les dialogues cérémoniaux yanomami : une esthétique politique de l'efficacité métaphorique. Les dialogues cérémoniaux yanomami (wayamou) sont une forme ritualisée d'échange verbal destinée à la résolution des conflits entre les communautés. Ce travail décrit et analyse ces dialogues en tenant compte : a. du sens de

* Universidade Federal de Santa Catarina [kamiyekeya@gmail.com]. 
son caractère métaphorique ; b. du rôle des connaissances acquises lors des rêves ; et c. de la façon dont les dénominations données au territoire socialisent l'espace, tout en le peuplant non pas seulement de communautés mais aussi de ressources et de possibilités d'échanges. J'essaierai de montrer que cette combinaison de caractéristiques relève d'une esthétique politique propre au chamanisme. Cette proximité suggère une continuité entre différents types d'agence politique et religieuse. On pourra ainsi tenter de réduire les distances que l'anthropologie amazonienne a crée entre l'analyse de la politique entre les humains et celle qui se tient entre les humains et les non-humains. [Mots-clés : dialogues cérémoniaux, Yanomami, métaphore, politique amérindienne, puissance d'agir.]

\section{Introduction $^{1}$}

The Yanomami live on a vast territory straddling the Venezuela-Brazil frontier in some 400-500 communities, dispersed through lowland forest and highland savannas. Communities vary in size from a few households to a couple of hundred people living in a circle of domestic places around a central plaza, either under a single circular roof, or in a number of extended-family houses. Inter-village visiting is constant for quotidian affairs and regular for more ritual occasions like funerary ceremonies. From the standpoint of any given community, the network of material, marital and ritual reciprocity defines a group of allied communities. Further afield, the exchange of harm in the form of raids, sorcery or shamanic attacks is sustained with a number of present and past enemies. In these crudest of terms, Yanomami inter-community politics revolves around the administration of these relations, through all forms of exchange (for a fully fledged analysis, see Albert 1985).

The wayamou ceremonial dialogues play an important role in this political field. They are a ritualized form of verbal exchange aimed at the resolution of conflict between communities whose status as allies or enemies has become blurred, and is hence at issue. This means that those who engage in the dialogues normally live at a remove, but still within the range of mutual influence. A contrast with the dialogues is offered by the morning and evening harangues of influential elders, called patamou - meaning to do or behave as an elder - directed at coresidents. These monologues' moralizing content looks to create a collective disposition for economic affairs; air and defuse local grievances; and, in general,

1. For fieldwork in 2010, 2012, and 2014 I counted with the aid of Instituto Brasil Plural (IBP) and Grupo Socio-Ambiental de la Amazonia Wataniba. Fieldwork in 2015 was carried out as part of my post-doctoral project « Two Yanomami devices for political mediation with alterity: indigenous organizations and ceremonial dialogues (Amazonas, Venezuela) », financed by the CAPES foundation of the Ministry of Education of Brazil, Project No. BEX: 0026/15-8. I would like to acknowledge the most valuable comments Stephen Hugh-Jones and Javier Carrera made on the initial draft, as well as those of the anonymous reviewers. 
orient relations within the community, as well as its standing facing other ones (Carrera 2004). Whilst the patamou monologues seek to avoid the degradation of conviviality into strife, conflict and division, the wayamou dialogues seek to convert suspect exchange relations into mutually profitable ones, or at least settle the mutual status of socially and geographically distant communities.

The wayamou dialogues and their variations (himou, teshomomou) can take place in the context of the elaborate funerary ceremonies where allied communities arrive at the residence of the deceased by invitation. ${ }^{2}$ Alternatively they can occur independently, in which case the visitors arrive, perhaps after one or more days' walking, engage in the dialogue during the night, have a restorative meal in the morning, exchange goods and leave swiftly.

The wayamou dialogues are a strictly nocturnal affair. After the visitors are received, as darkness settles, the first pair of visitor-host participants begin. The earliest to participate are the youngest and least experienced. As the night proceeds, more versatile speakers succeed the inexperienced, and towards dawn the elders display their virtuosity. The morning light puts an end to the verbal exchange and inaugurates the exchange of goods, invariably a topic of the dialogues themselves.

In each dialogue, one participant takes the lead, speaking or chanting his phrases, whilst the other, closely crouched in front of him, responds by repeating his words identically or with a slight variation. The phrases can be sung or spoken, they can be broken into multi-syllable part-phrases, or even monosyllables. The response has to be fast, to the extent that sometimes an interlocutor guesses the lead's phrase before he finishes. The voice - spoken or chanted - is usually very vigorous, often intimidating, as the speaker harmonizes his words with the slight swinging of his body and the slapping of his hands on his crouched legs, punctuating the force of his words. He may also be standing up, moving side to side facing his contender, perhaps brandishing his bow and arrow. The respondent must repeat the words of the lead, even if what is said is a recrimination; he may at times just acknowledge the rightfulness of the lead's words. He may repeat phrase by phrase, or syllable by syllable, depending on the lead's format, or await a separated multi-syllable sequence to end and then utter the reconstructed phrase. At times, a witty response may, for a few phrases, switch the lead of the exchange to the respondent, but in general the convention is that after the lead has finished, it will be his turn to listen and repeat the words of his interlocutor. As the two interlocutors consume themselves in this verbal duel, which tests their physical and vocal stamina to an extreme, everyone else listens from their hammocks.

Visitors relay each other, as do hosts, although these successions need not be simultaneous, and depend both on individual stamina and ability, and on

2. Himou and teshomomou are carried out by day and are stylistically one with wayamou. The former take place when making formal solicitations in other communities; the latter consists of short discourses given on the occasion of the entry of visitors into a community during a feast (Lizot 2000, p. 165). 
the number of able speakers present (Lizot 1994b). A bid to replace a fellow participant is initiated from one's hammock with an $i t^{h}$ ouwei « descending » (from the hammock) chant, consisting of longer phrases sung at a slower tempo.

$$
* * *
$$

In very general terms the wayamou is functionally, aesthetically and linguistically of a kind with other Amerindian ceremonial dialogues, as analyzed by Urban (1986): it occurs within a context of potential social disruption among socially distant peoples (but see Alès 1990, p. 228 for caveats); it semantically and pragmatically recalls culturally specific means to achieve social cohesion; it is a distinctive, recognizable and stylistically marked form of dialogue; it stages the mutual implication of verbal with more generally social forms of solidary interaction; and host-visitor pairs take alternate « semantic » and « responsive » turns. Additionally, this Yanomami example shares several more specific characteristics with its functional homologues elsewhere in Lowland South America: it is revelatory of principles, and participates in the negotiation, of the contours of wide-scale social organization, as is the case among the Trio, Waiwai and Wanano (Rivière 1971; Fock 1963; Chernela 2001); it is an artful and competitive duel-like speech genre that takes time to master and thus distinguishes the younger from the elder in terms of quality of performance, as is described for the Trio (Rivière 1971) and Jivaro ensemble cases, with which it also shares the importance assigned to vocal potency and vehement expression (see Gnerre 1986; Descola 1996, p. 165-172).

There are also important differences either accountable to the phenomenon itself or to the way it has been analyzed. In contrast to what Rivière (1971) and Fock (1963) say about the language used in Trio and Waiwai dialogues, respectively, wayamou does not use archaic words or those that are otherwise distinct from those used in everyday talk, though certain metaphorical constructions and a few words would appear to be specific to or at least most common in wayamou (see examples in Lizot 1994b). Despite the use of stereotyped, formulaic forms, as I shall try to show in the examples below, it is hard to characterize wayamou as void of communicative content, that is, where the phatic as opposed to message-bearing function is definitely overriding, as is said of the Jivaro cases (Gnerre 1986; Descola 1996; Surrallés 2003). Last but not least, the weight of improvisation in the expert execution of wayamou places Yanomami wayamou on the improvisatory pole of formalized speech genres when compared, for example, with Xinguano « chiefs' conversation » (Franchetto 2000) or Tukanoan ceremonial chants (Hugh-Jones, pers. comm.) based on the recital of memorized canonical and/or esoteric knowledge, with little or no room for improvisation.

$$
* * *
$$


Before laying out the structure and argument of this paper, it is best I describe the context that made it possible. Most of the wayamou sessions I have witnessed occurred during assemblies of the Brazilian Yanomami organization Hutukara (2008, 2010, 2012), involving Venezuelan Yanomami invited to the meetings in the role of visitors, and a mixture of Brazilian Yanomami in the role of hosts. In the last two of these meetings held at $T^{h}$ ooth $^{\text {h }} t^{h}$ opi (2010) and Watoriki (2012), I recorded the wayamou dialogues of Marcelo Borges and Alfredo Silva, Yanomami elders from the Parima highlands, and members of the newly created (2011) Venezuelan Yanomami organization Horonami. In fact, the visit to the 2010 Hutukara assembly served as a catalyst for creating Horonami. These wayamou sessions are held on the first night of the four-day meetings that during the day are engaged in discussing different aspects of Yanomami-state relations (health, education, illegal gold mining, land invasions, etc.) among the Yanomami themselves, and with state representatives. In 2010, the discourses of the Parima Yanomami focused on demanding information as to how to create an organization and secure financial aid from White (napë) allies for this purpose. In 2012, with Horonami just being created, their requests were for advice and mediation with Whites from their more experienced counterpart (Hutukara).

Between early 2013 and late 2015, I transcribed and translated fragments of these dialogues with three Yanomami collaborators: Marcelo Borges, Donaldo Silva and Bruno Borges. Part of this work yielded a Yanomami-only publication (Borges et al. 2015). All the wayamou extracts presented below are taken from this book and are the fruit of this collaborative work, from which I have benefited greatly, not least because my collaborators' comments as we transcribed/ translated provide me with an indigenous perspective on wayamou that I could have hardly elicited or noticed otherwise. On the other hand, an indigenous organization's assembly is a novel scenario for the holding of wayamou. Beyond its more conventional socio-political context, this creative extension of wayamou performance gives all the examples I present below a particular inflection, where an inter-community ritual form comes to include an inter-ethnic content.

$$
* * *
$$

In this paper I describe and analyze the wayamou dialogues, taking a closer look at the following:

a. The significance of their tropic nature. Although the use of the whole field of verbal resources and the densely metaphorical character of wayamou is evident in Lizot's previous translations/interpretations of segments of these dialogues (1994b, 2000), I want to dwell on the Yanomami understandings of metaphorical and circumventing language and how it does its work. It is also true that trope is given little consideration in the wider field of comparable ceremonial dialogues (see Urban 1986; Monod Becquelin 
and Erikson 2000; Rivière 1971; Fock 1963; Gnerre 1986; Surrallés 2003; Chernela 2001). This metapragmatic approach shows how trope is associated with conflict resolution; indexes highly valued knowledge and skills contributing to political persuasion; and indexes past relations and exchange expectations with the necessary diplomatic indirection.

b. The role played by knowledge and skills acquired in dreams. The importance of dreams that comes vividly forth in Kopenawa's auto-ethnographic account (Kopenawa and Albert 2010) has, somewhat surprisingly, not been matched by its analysis in Yanomami studies. As with other influential aspects of Yanomami life like shamanism and hunting, the ability to « dream afar » is fundamental to excel in wayamou. Dreaming is the source of knowledge of distant places, peoples and things to be displayed in " naming the forest », as it is of the verbal skill to aspire to expert performances.

c. The manner in which «naming the forest » socializes space. Urifi wëyët, glossable as «naming the forest» or « naming places », is a fundamental aspect of wayamou discourse, where all sorts of features of the landscape and its associated peoples and resources are named. Whereas Lizot (1994b) shows this topographic naming to be a way of socializing the forest, in concentrating on the intrinsic relation between places, peoples and resources condensed in the notion of urifi, I want to show how such socialization is achieved mainly by indexical means. I draw here also on Alès' work (1990) to suggest that the inter-indexicality between place, people and resources also allows for the referencing of events and peoples gone by, a necessary form of diplomatic indirection among a people who hold a strict prohibition on naming the dead.

Attention to wayamou's metaphorical efficacy in conflict resolution and its dependency on dream-derived knowledge and skill provide evidence for an argument I will only spell out in full in the conclusion: this combination of features in wayamou discourse delineates an aesthetics of political agency of a kind with that of Yanomami and other forms of horizontal shamanism (Hugh-Jones 1994) in Amazonia. Such proximity suggests lines of continuity between political and religious agency and comes as an invitation to bridge the gap Amazonianist anthropology has carved between the analysis of intra-human politics and that between humans and non-humans.

Further reinforcing the argument that wayamou and shamanism share discursive aesthetics and knowledge practices (dreaming) is the premium placed on various forms of improvisation as well as the perspectival person deictics deployed in the dialogues. Both these topics are dealt with in specific sections.

All the examples presented also demonstrate how expert wayamou speakers can metaphorically translate the contents of inter-ethnic politics into the language of exchange, myth, cosmos and Yanomami everyday life. This ability to 
make the novel resonate with the known has been recognized as a particularly shamanic expertise deployed within the ongoing transformations of colonial and post-colonial Amazonia (Carneiro da Cunha 1998).

To my knowledge, this connection between ceremonial dialogues and shamanism has not been as clearly stated in the literature, even though Alès (2006) has rightly noted the use of gender shifting as demarcating a special ritual context in both wayamou and shamanic discourse. Elsewhere, Erikson (2000) has analyzed ordinary salutations among certain Amerindians as means to resolve the suspect ontological status of visitors. The tension surrounding formal visits among the Candoshi also leads Surrallés (2003) to think of the non-linguistic performative aspects of this welcoming ceremony in terms of laying an ontological common ground as the precondition for communication among equals (human/Candoshi). In both cases, it is the renowned Amerindian mistrust of appearances (spirits and people are not always easily told apart) that calls for measures to dispel ontological doubts.

Comparatively, I don't think wayamou intends to clarify the ontological status of visitors, mainly because any such suspicions will have been resolved in the «presentation dances » involving war mimicry and sexual bantering with which Yanomami enter host communities in formal visitations. Wayamou only commences after dusk, once visitors have settled in, and thus should not, strictly speaking, be considered a welcoming ceremony. Neither is the tension surrounding the dialogues tied to ontological concerns. The danger of wayamou lies in people having to talk about delicate subjects - past grievances, hostilities, the dead - and recriminate and make claims on each other - current problems, requests of exchange or alliance - the outcome of which is highly uncertain. Wayamou constitutes a political edge between peace and conflict.

Ethnographic differences notwithstanding, with Erikson and Surrallés I want to approximate human and inter-specific politics, but whereas they deal with discursive and aesthetic practices to reduce the ontological ambiguity of others - are these visitors human or spirits? - my tack, complementary to theirs, posits a single set of discursive and aesthetic practices to influence others - be they human or spirits.

$$
* * *
$$

Given that previous analyses of wayamou (Lizot 1994a, 1994b; Alès 1990, $2003)^{3}$ have already established its correspondence with Yanomami social organization; its role in the regulation of conflict, and hence in defining the

3. Earlier, less exhaustive works that deal with the wayamou at different lengths include: Cocco (1972), Shapiro (1972), Eibl-Eilbesfeldt (1971) and Migliazza (1972). For a critical appraisal see Lizot (1994b). 
relevant social categories of allies and enemies; the importance Yanomami place on exchange in the establishment or breakdown of alliance, and hence the continuity between verbal and physical violence; my concentration on these sociological aspects will be limited.

My approach is semiotic and performative, detailing how trope effects the sociological work attributed to the dialogues, that is, I focus on metaphorical and indexical processes (semiotics) deployed in hope of influencing interlocutors according to the speakers' political expectations (in this sense performative). This contrasts with the general trend in which the absence of content in similar ceremonial dialogues has led analysts, in line with Urban's (1986) comparative study, to understand their pragmatic effects mainly in terms of achieving social cohesion in situations of tension. ${ }^{4}$

\section{Metaphorical language and conflict resolution in wayamou}

Working with the wayamou dialogues, my friends conjured the expression $\tilde{a}$ wã poapou to match my sense of "metafora " in Spanish. $\tilde{A}$ wã poapou conveys the sense of circumventing speech. The key part of the expression is the root poa-. When asked to exemplify its use, the first image offered was that of a creek from which a new arm is born after heavy rain, circumventing a piece of higher ground. As he spoke, Marcelo's hands described a skirting move. As transcriptions proceeded, it became clear $\tilde{a}$ wã poapou included all sorts of linguistic devices that avoided straightforward ways of saying things. Considering it is circumvention that Yanomami emphasize, I shall be referring to metaphor in this very wide sense, subsuming, as Wagner (1972) does, all forms of trope as against lexical denotation. It is important to note from the outset that the use of metaphor in wayamou should not be understood as a way of hiding true intentions or related to a general « distrust of language as a medium for knowing personal intentions or social states », as it has been described for New Guinea peoples (Stasch 2011, p. 168). For example, it is conventional that desired objects in wayamou may not be requested explicitly; instead, they must be obliquely alluded to, in short metaphorical sequences. Talking quite off-handedly about this characteristic way of asking for things, one Yanomami described the circumlocution involved in the following terms: one must lie to (nasi-), but not deceive (mirã-), one's interlocutor. As we shall discuss below, metaphor is about diplomatic appropriateness, political persuasion and artful display all conjoined in an aesthetic efficacy.

4. Lizot (1994b, 2000) himself is hesitant on this subject. On some occasions he stresses the absence of message transmission; on others he simply states that the analysis of wayamou as a sociological fact and the semantic interpretation of the dialogue are, to an extent, separate exercises. 
My colleagues concur that only elders know how to metaphorize well in wayamou. When youngsters participate, they name things, places and animals directly. These words are considered « worthless » (thë a kua pëa, thë ã nowã kuami). The clarity of youngsters' words is their demise. Elder's wayamou, in contrast, is true and important (peheti). In the context of wayamou, «clear words » (t $t^{h} \ddot{e} \tilde{a}$ wararawë) are inadequate, whilst metaphor is the mark of correct performance.

When Yanomami comment on the wayamou in the abstract, it is conflictive contexts and their resolution they presume and emphasize. In a generic rendition, when communities in conflict come together for wayamou, from the beginning, one host after the other will reprimand the visitors for their wrongdoings; this is forceful, dangerous, effective talk (wã wayu). The belting of criticism continues through the night and only towards dawn, after people have spoken their minds without restriction, will the more experienced seek to bring the dialogue to a compromise for the maintenance of peace. This phase of friendship talk is characterized in terms of okeprou « calm oneself down » or okemayou « to calm each other down ». The wayu/oke- opposition is important. Wayu designates powerful substances like hallucinogenics, tobacco and poisons as well as enemies and dangerous situations. Okewë designates tasteless food, substances without effect over the body, and more generally harmlessness. What is at stake is the transformation of affective states. The aggressive criticizing is necessary to appease people, disposing them for reconciliation once they have become oke « calm » (for similar renderings of this sequence, see Kopenawa and Albert 2010, p. 397 and Alès 2003, p. 212).

The ability in wayamou is referred to as being aka hayu, an expression that more generally refers to the ability to speak the Yanomami language correctly. The term is opposed to aka porepi, literally « to have the tongue of ghosts », and refers to small children who don't yet speak properly, mutes and those who don't know how to participate well in wayamou. Not having the skill for wayamou is thus likened to not being able to speak at all. In a sense wayamou epitomizes language and speech, which is why the staccato style of wayamou, with the predominance of incisive short phrases and agile use of linguistic resources, appears, though to a lesser extent, in elders' evening and morning harangues (patamou), as well as in any serious conversation (see Lizot 2000). In this way of talking, ideas are uttered as a monologic enchainment of verses, as in a poetic declamation. This contrasts with everyday talk, which is closer to the format of a conversation, being more dialogic, straightforward, and with a different tempo.

But aka hayu also refers to a person's adroit handling of exchange relations and is an accolade of influential elders who exemplify Yanomami exchange morality. In contrast, aka porepi may also indicate a person who gives things away without return and hence doesn't know how to make him/herself respected (Lizot 2004 p. 8). In myth, Pore « Ghost»-the key term in aka porep $\dot{t}-$ is the master of 
plantains and incarnates anti-sociability on several accounts: he is stingy, doesn't speak well, and scolds the Yanomami for stealing from his garden (Lizot 1994b; Carrera 2004). The linguistic and mythological connection between speaking well and the morality of exchange is very explicit. As Lizot says, Yanomami « establish an equivalence between the exchange of goods and oral communication, that is an exchange of words » (1994b, p. 64). So whereas with Urban we can say wayamou is a " "model for" ordinary conversation, and, indeed, social interaction more generally », more than « conveying a message about solidary linguistic and social interaction » $(1986$, p. 371), what wayamou does is reflect the solidarity Yanomami pose between linguistic and social interaction.

$$
\text { *** }
$$

We have mentioned that it is youths who initiate the wayamou when night falls, and that the clarity of their words makes for crude, disappointing performances. Youths initiate the wayamou to gain experience. Not knowing what to say, they anxiously limit themselves to conventionalized formulas, void of communicational content (Lizot 1994b). Voidness notwithstanding, my colleagues stressed that youngsters basically screw things up: they may instigate violence or deny exchange and assistance. It is left for the elders, later during the night, to mend their words and push for peace:

Oshe pë rë kui, pë ã wariaìhe, «pë niya shei, pëfë topëimi », ma kui, pata pëni pë wayamou nomihio tëhë, pë ã wayamou sharirou.

Youngsters speak badly/mess things up with their words, [they say] «we will hit you », "we won't give you anything », but when elders speak in turn, they straighten the wayamou (they offer things and assistance; they respond to demands).

Pata pë rë wayamowei tëhë, oshe pëni thë ã rë warianowehei thë ã niya katehaihe. Oshe pë pufi taomi ha.

When elders do wayamou, they will mend the ugly/wrong words of the younger ones, because youngsters are not wise/hospitable (they don't foresee the consequences of their acts).

From these descriptions, I want to stress the link between metaphorical skill and pacifying competence ascribed to elders' aka hayu speech in contrast with that of youngsters, who, like Ghost, exemplify the link between bad speech and anti-sociability.

\section{Dreaming and naming the forest}

How does one become aka hayu? For starters there is individual talent and personal interest. To learn wayamou one must live with expert speakers and 
pay attention to their chants. It is said eating hot peppers prepares the throat for forceful and fluid speech in wayamou. Alès mentions that having the spirit of the short-tempered "Lightning Woman ", Thafirayoma, is essential to being aka hayu. Her lightning/fire is associated with « eloquence, volubility and phonic potency » (1990, p. 238).

On the other hand, there is dreaming. In general, dreams in which one sees, listens to, or engages with animal masters, mythical ancestors or other forest spirits are a fundamental source of knowledge and capabilities. Oneiric visions and travel are central to shamanism and hunting. In relation to wayamou, I was told that in mythical time Yanomami ancestors approached amoa hii, the « tree of songs », attracted by the beautiful melodies that sprang from it and that they had never heard. The ancestors retained these songs, acquiring the ability for wayamou. Today one may dream with this scene to do well in wayamou.

Certain birds are considered aka hayu, and thus are good dream-targets to become aka hayu oneself. Three bird-spirits - shitipaririwë, perhaps the buffthroated saltator; 5 ayakorariwë, the yellow-rumped cacique; and kirakira moku, the red-fan parrot - were listed to me as aka hayu birds who retain their vocal ability of mythical times, speaking Yanomami language and holding wayamou among themselves. According to Kopenawa, shitipaririwë and ayakorariwë, among other birds-spirits, are « masters of chants » and have a prominent role in bestowing vocal ability on shamans (Kopenawa and Albert 2010, p. 95, 142). Alès (2003, p. 222-223) also mentions yarapiariwë, a kind of sparrow, and arimariwë, a species of parrot, as bird-spirits that enhance speaking abilities.

But perhaps the most relevant connection between dreams and wayamou is related to urifi ã wëyët, « naming the forest ». The first time I asked Marcelo, point blank in $\mathrm{T}^{\mathrm{h}} \mathrm{oot}^{\mathrm{h}} \mathrm{ot}^{\mathrm{h}} \mathrm{opi}$, why Yanomami engage in wayamou, he simply said they want to name the forest. Wayamou dialogues are replete with sociogeographic references: present and past places of residence, rivers, rapids, large rocks, mountains, bamboo groves, etc., along with their associated peoples. As Lizot (1994b) says, naming the territory socializes space. In this connection all sorts of Yanomami groups are mentioned. Apart from specific communities, more generic social categories like the shamat ${ }^{\mathrm{h}}$ ari and the waika are recurrent. These terms form part of the Yanomami sociological landscape and constitute a relational opposition: the former refers to peoples living south or west of the speaker's community, the latter to those living north or east (Lizot 2004, p. 456). Specific peoples such as the parafiri (a term associated with groups in the Parima highlands) and the napë (Whites) are also frequent sociological references.

5. Lizot has Shitiparimi as an unidentified small bird with « a very melodious and varied chant » (2004, p. 396). A similar bird name Sitipari si, most probably the same bird but pronounced differently due to linguistic variations among Yanomami groups, appears as saltator maximus in Kopenawa and Albert (2010, p. 657). 
In naming the forest, one mentions not only the regions one inhabits or visits, but also those one knows only in dreams. In effect, dreams with distant places are the veritable source of the ability to name the forest, as they are for shamanism and success in hunting. One of the terms for dreaming, $t^{\text {h }}$ apimou, linguistically includes this reference to distance, its root $t^{\mathrm{h}} a p i$ - also appearing in $t^{\mathrm{h}}$ api ha, meaning «further away » (Lizot 2004, p. 434). Correspondingly, $t^{\mathrm{h}}$ apimou means to have a premonitory dream, often about the proximity of visitors or enemies, or to dream about distant places or people (Lizot 2004, p. 434). ${ }^{6}$ It is not enough, then, to recite places one has heard about, my colleagues insist; one must see them close in dreams, to know and then name them during wayamou. It is as if dreams had a superior capacity to fixate knowledge.

Let us now turn to Marcelo's It $t^{h}$ uwei chant, for it is a good example of naming the forest and its links with people and resources.

1. « rafaka shiiwë këki upraa fe rë weyape, ei këki fe ã ni watupapi rãi fe rë weyape, ya e ãfã wëai yaio sho », wamaeki pufi kuu hõã hokëprou yaiwë ha

« The rafaka shiiwë bamboo grove that stands afar, the vultures raising flight indicate its presence, I will name it at once » you (second-person plural, refers to all hosts in the community) are thinking this as you rise for the wayamou

2. « ha, ei rafaka si koropirimi, ei oru këki upraa fe rë weyape, ya e ãfã ta wëa sho, yoyo a wãri tharema a wãri wapë » yamare nofi thapou yaio ta përa sho

« The rafaka si koropirimi bamboo grove, this snake that stands afar, I will name it immediately, he will kill a yoyo toad and eat it », what does it matter [if] you really regard us like this?

Lines 1 and 2 find Marcelo impersonating his hosts, who will name (ãfã wë-) two bamboo groves. These bamboos, generically called rafaka, are used as arrow points, and are correspondingly also called rafaka. To mention the grove is also to name the arrowhead. In 1, rafaka shiiwë, glossable as « shitting point », is a type of arrowhead said to cause a victim to excrete after it has been struck. In 2, another arrow point, rafaka si koropirimi, is named. This bamboo has a slightly rough surface and is thus likened to the skin of a snake, emphasizing its deadly efficacy. In saying his hosts will « name » these places, Marcelo is in fact asking them to offer that of which they have plenty, for the arrow points metaphorize any exchange object, and in this particular case, they stand for an explanation about Hutukara. Line 2 is a variation of 1 , repeating the request but adding its motive. « He will kill a toad and eat it» means, at

6. Kopenawa insists on shamans' ability to dream afar, in opposition to normal Yanomami, who dream close - making the exception for good hunters. The contrast is sharper when compared with Whites, who don't know how to dream afar. Dreams are Yanomami people's specific source of knowledge in contrast with Whites' writing and formal education (Kopenawa and Albert 2010, p. 490-503). 
a first level of trope, that, having obtained arrow points, Marcelo will hunt game - mentioning a toad is an understatement. The real sense is that, having had Hutukara explained to them, he and his fellow Yanomami will create an organization in Venezuela (as in fact happened). Marcelo's impersonation is a friendly request: Hutukara the a niya wëai ... rimimayou thë a, pufi topramayou $t^{h} \ddot{e} \tilde{a}$. « [The interlocutor] will explain about Hutukara ... this is alliance talk, words to content one another. »

Two important metaphorical correspondences appear in these lines: first, arrowheads may stand for anything one may desire; and, second, naming an object or the place where it flourishes is tantamount to offering it (or alternatively demanding it). In fact, the term wëyët means to give or offer something, whereas $\tilde{a}$ wëyët, where $\tilde{a}$ means sound/voice, is to talk about or explain something, and in urifi $\tilde{a}$ wëyët is to name specific territories. Finally, ãfã wëyët, in which $\tilde{a} f \tilde{a}$ means « name », is to « promise, assign a name » (Lizot 2004, p. 453).

3. ha, waika wamaki përipraini, waika wamaki përipraini, wama ãfuku pëfi kãi kemarema, e ãfuku hukukuaai yai ya ta përahe

You (second-person plural) waika who live dispersed, you waika who live dispersed, you have arrowed a toucan (lit. you have made the colored tail of the toucan fall), what does it matter [if] you pluck the tail feathers (to offer them)?

4. ha, waika wamaki rë përiprai, wamaki rë përiprai, wama ãfuku pefi kãi kemarema, e ãfuku niya huuai yai a ta përahe

You waika who live dispersed, you waika who live dispersed, you have arrowed a toucan, what does it matter [if] you place the tail feathers in my earlobe?

The general sense of lines 3 and 4 is glossable as « you people gathered here, you are well supplied with manufactured objects and aid from Whites, you have Hutukara: let us know how we can achieve such wellbeing with an organization ». In my colleagues' terms: wamare shiroko shimatihe, wamare topëi totihiopë, matohi a nakaimi, organización a nakat. « Don’t send us home empty handed, give us plenty, he [Marcelo] is not demanding things, he is asking for the organization. »

Several tropes are involved. First, afuku, the red and yellow feathers of the toucan (mayepi), is a metonymic reference to the bird whose feathers are used for adornment. Second, the adornment substitutes for objects and, again, the information on Hutukara's process and success. The waika in these phrases refer to the Brazilian Yanomami, given the latter's location (to the east of Parima).

5. waika pë rë përiprai pë rë kuini, hokoro a thai totihia mrahei, waika pë përihou totihia pëta

The waika living dispersed, they don't make bird-hides, the waika just live without reason 
6. pë ni hëtmipi si fa niyaoni, pë rë riyëhape

They kill many cotinga birds with arrows and beautify themselves

Lines 5 and 6 point to hosts' having an organization and material wellbeing. But line 5 is an antiphrasis. Although it is said the waika don't make bird-hides, implying they don't have adornments, quite the opposite is meant. "Wamaki nïhìte... paushi tharëwë. Wamaki sinapì thë hirimaou kuwë ma kui, nìhĩte wamaki... wamaki matofipi waikiwë!... wamaki hori ma rë mrai, yamarëki ta topë rë! 》 "Y You (waika) are good hunters, you are people with adornments. It sounds like "you are bad hunters" but it means "you are good hunters" ... you are full of goods ... it is clear you are not in want for them, give us! » The inversion of 5 is evidenced in 6 . The bright blue breast skins of the cotinga are used as earlobe adornments by Yanomami men. Again, the adornment substitutes for objects, and these in turn for the organization. In Marcelo's rendering: " Wamaki napëprou wakirayoma, kafë wamaki iropi si rë taowei naha ya kuaai mí fetuopë. Organización ya thë wari. " "You have already become like Whites [you have their objects that have come from stable relations with them], just like you have clothes, I, on my part, want to have them too. I am asking about the organization. »

7. niyayopë u katia payëkëa fe rë weyape

The river Niyayopë that lies afar

8. wetini pei wã thë pë hapa hõã shurukai yaio ma ta thawë

I wonder who really started the war there a long time ago?

9. urifi ã wã nofi kuo mrãõpë ha ya përia totihia yai ya kuteeni

there is no longer war there, because I live there [I can explain our situation]

10. kihi shokekere thë pariki praa fe rë weyarati

the Shokekere mountain range that lies afar

11. kihi hatakuat ${ }^{h}$ ari pë rë përihorati

those chachalaca spirit-people who live afar

12. kihi rafaka warowaropiwei këki rë uprape

that warowaropiwei bamboo grove that stands afar

13. $\tilde{i} h \tilde{i}$ rë ya ki âfã wëkei $t^{h} a w e ̈$

I am to name/offer it?

From line 7, Marcelo begins to name his region (Parima). The niyayopë, « shooting arrows at one another » creek, crosses the savanna home to several 
communities. It lies « afar » because Marcelo is speaking at $T^{h}$ oot ${ }^{h}$ ot ${ }^{\text {h }}$ p $\dot{t}$, which is far from Parima. Lines 8 and 9 refer to the region being named after prolific warring in the past (I am unsure about a precise translation for line 9). In line 10, Shokekere, the " circular » range, refers to an arc-like range of mellow hills in Parima. In line 11 the chachalaca spirit-people who live at Shokekere is an oblique reference to the Yanomami who live there. Why the specific reference to spirits and why the chachalaca, I could not discern. My colleagues said this is simply pata the a a a ka hayu th $\ddot{e} \tilde{a}$, " elders' speech, experts' speech. " Line 12 names another bamboo grove, this time a specific place in the region of Momoi (north of Parima). At this point Marcelo is implicitly asking his audience: « Do you know this place? » My colleagues add: pë rë hekuramouwei pë rë kuint $t^{h} \ddot{e}$ shirõ niya taihe. Wayamorewë pëni thë taihe. «Only shamans will know this place. Those who excel in wayamou will know this place. " Shamans and expert wayamou performers dream a lot, which is why they will not only name many places but also recognize them when spoken by others. In line 13, asking whether he will name this region brings us again to the intrinsic link between naming places and offering their resources. Marcelo is saying the visitors to the assembly have brought nothing to exchange. How is he to name a place if he has nothing to offer? Yamare wayamomai yaro, ya hore kuu pëtao, ya nofimou pëtao, urifi ya wã wëyët pëtao. " Given they incited us to wayamou, I mention this in vain, I am just being friendly, I am just naming the forest (in vain). " In broader terms, this lack of objects refers to the dire situation the Parima Yanomami find themselves in. An overgrown population has drastically reduced game available and induced deforesting, making the land infertile for gardens. A relative bonanza of goods and food previously coming from New Tribes Mission missionaries, and then directly from the government after their expulsion in 2006, has also dwindled in the last few years. My colleagues comment: ya $t^{\text {h }} \ddot{e} \tilde{a} t^{\text {h }}$ apou pashiami, matohi ya thapoimi, organización ya thapoimi « I have little information to offer, I have no objects [to exchange], I have no organization », yamaki ni rë prëaiwei, ya thë a niya wëat, wama thë ã tapë, «I will explain to you how we suffer [in Parima] for you to know. »

\section{4. kihi hiomari pora rë yaupe}

The Hiomari bird falls that hang afar

\section{5. kihi shamathari pë përiprawëni}

the many Shamat ${ }^{h}$ ari who live there

\section{6. këki ni shamapi fa waaheni}

they eat plenty of tapirs

\section{7. îth pë wai ma yokaaihe tëhë}

but they eat by themselves (away from us, because they live in another region) 
18. üasi, kamiyë shamathari yamare hõa hore hore rë hiraporayoi younger relative, you have being calling us Shamat ${ }^{h}$ ari mistakenly

19. kamiyë shamat ${ }^{\text {ari }}$ ya mrai

I am not Shamathari

20. kamiyë fei pirisi theri ya rii

I am from the savanna

21. kihi horomopë këki pepi ha

at the foot of the Horomopë (whistling) mountain

22. kihi mõrõ a wai rë titirati

the small armadillo in his burrow afar

23. fesi wai ma shuwëo tëhë

despite its shell being small and thick

24. " ya e fesi ã wai yupo sho"

«I will request a small shell at once »

25. awei ũasi, wamaki pufi kuu waikiwë rë

Yes, younger relative, you (second-person plural) are already thinking this

Lines 14-25 continue naming toponymic features of Marcelo's region but establishing a contrast with people living down-river from Parima, people they call Shamat ${ }^{h}$ ari. It is said they eat many tapirs because they live in a game-rich forest, and not the savanna. The contrast is introduced to stress Parima people's lack of game, but also because the host Yanomami were calling their Parima visitors "Shamat ${ }^{h}$ ari $»$. There is an issue of perspective here. Whilst the hosts consider the visitors Shamath ${ }^{h}$ ri, the visitors use Shamathari to refer to this aforementioned down-river people. Here again my colleagues comment on dream knowledge: « In $T^{h}$ ooth $t^{h}$ opi Yanomami also dream, they also know distant places. When Marcelo names the Shamathari region [in his audience some] will say "oaoaoa, I have been there in dreams, Marcelo is speaking the truth". They will think "he is either a warrior, a good huntsman or a shaman". He is a dreamer. »

After naming elements of Shamathari topography he then refers again to a hill in his region, Horomopë, "whistling mountain ». The reference to the small armadillo in lines 22-24 is again a reference to the Yanomami who live at the base of this mountain, that is, themselves. The small and thick-shelled armadillo makes for a poor exchange object and is a metaphor for the undignified way the 
Parima Yanomami are living. The final lines refer to how Marcelo imagines that his hosts are eager to learn about how they live, even if they as visitors have really not much to offer in terms of goods or information.

$$
* * *
$$

Let us take stock on some of the connections already visible in this segment. First: on exchange and its metaphorical and sociological dimensions. Marcelo mentions many exchange objects: different arrowheads, ornaments, a shell. Lizot (1994b) underscores that items requested during wayamou are to a large extent « imaginary », for they do not correspond to what actually changes hands in the morning. This in part is due to the indexical function of many (surely not all) requests: my colleagues insist such demands are « alliance talk » uttered not in pursuit of the often trifle object mentioned, but as an indication of the general disposition to exchange and aid each other. On the other hand, they insist that in reality they are after more valuable items (see Alès 1990), which suggests that specific phrasings of demands form part of the poetic conventions of wayamou. Furthermore, in the segments presented (here and below), we see speakers have a given objective, they state over and over, enchaining metaphorical sequences, couching their demand with a variety of assertive, subtle, and witty overtones. The language of exchange lends itself as a meta-metaphor for such objectives.

The recursiveness of « exchange talk » and « exchange do », the intrinsic implication of expert oratory and adroit handling of exchange relations, are mutually reinforcing statements about exchange itself. As Lizot (1994b) and Alès (1990) both state, the meaning of all the exchange talk in wayamou requires taking a step back to grasp its overall sociological dimension, which is none other than to reiterate the importance of reciprocal exchange for the sustenance of a peaceful relations. Whilst it can be said, following Urban, that wayamou conveys, in semantic and pragmatic terms, " a message about how cohesion is and should be achieved » (1986, p. 371), we cannot forget that it also exhibits the very opposite of social cohesion without leaving the register of exchange talk. I am referring to the vehement airing of grievances that precedes and conditions alliance talk. In a very Maussian and Lévi-Straussian sense, wayamou exhibits the conceptual continuity Yanomami pose between war and peace, different in the « valence » of exchange, but not different in kind (Lizot 1994b; Alès 1990).

Second: on the connection between naming the forest, its people and resources. The first thing to note is that there appears to be a naming sequence: topographic reference, people, things.

\footnotetext{
Bamboo groves - Waika - adornments

River - mountain - chachalaca-spirit people - bamboo grove (arrow points)

Water fall - Shamathari - tapirs

Savanna - mountain - armadillo - armadillo shell
} 
This may or may not be a conventional sequence, but what is more important is that naming the forest exhibits an inter-indexicality between place, people and resources, whereby naming one element can index another. This feature of urifi a wëyët « naming the forest » is attuned with the way urifi is conceived by Yanomami, not just as a chunk of nature, but as a territorialized conjunction of specific human and spiritual presences, the outcome of which is a place with given characteristics.

We knew that naming the forest socialized it (Lizot 1994b). Now this notion of urifi and the inter-indexation of is components allows us to suggest a way in which this comes about. If the equivalence between the exchange of words and goods hinges on both being forms of exchange, I think the one between naming and offering/demanding hinges on both presenting something absent, on making it visible, and, for that very reason, available or subject to request. In Yanomami everyday life, objects in sight expose their owners to exchange (hence desired objects are kept hidden), but naming people is offensive (and hence avoided) because, as Lizot and Clastres (1978) analyze, the individuation that comes with naming invokes death (see Erikson 2000 for the opposite correlation of naming with life among Pano-speaking peoples). Naming the dead is an even greater breach of norms. In both cases, naming is indicative of ill feelings, and in the latter case (naming the dead) is taken as a challenge to fight. In general, verbal or visual presentification, avoidance and concealment are important performative forms of displaying appropriate comportment and means of compelling others to moral action (Kelly 2011). In naming a place, one may be indexing things and hence exchange possibilities. I was told as an example amid transcriptions: « If I name Puerto Ayacucho, I am speaking of the things they have there » (paraphrase). But in naming places one may be indexing people, which is crucial to bring the past to bear upon the visitorhost relation, for as Alès (1990) suggests, given the dead cannot be named, topographic naming is also a way of alluding to the past, evoking the memory of people and events gone by. We may add that features of the landscape are also testimonies of mythical events. This indexing rests on the intrinsic relation between place, people and things condensed in the notion of urifi and is achieved by circumlocution - making one thing present (things or people) by means of another (place). Part of the delicate art of naming the forest depends on a skillful play of allusions within the realms of exchange and of past relations according to the current political expectations of the speaker.

Third: on the importance of dreams knowledge and skills. One who does not dream with the tree of chants, with the eloquent birds-spirits, with distant places, will remain aka porepi - unfit for wayamou. Whereas wayamou stages a verbal contest, it is not only virtuosity that is at stake, but also knowledge itself: of the forest, distant places, mythical events and cosmological planes. Some phrases 
seem to have no other purpose than to display this knowledge, sometimes to challenge one's opponent, and here there is reputation to be gained and lost.

$$
* * *
$$

In my colleagues' comments on this wayamou there is a telling connection between « indigenous organization » and manufactured goods that requires some context for interpretation. At the time these Yanomami had no experience whatsoever of indigenous organizations, whilst they have been the object of political parties' and government agencies' attention for a couple of decades. In fact, during the assembly one of the Venezuelan Yanomami asked me whether Kopenawa was a representative of the governor or the mayor - the most wellknown political figures among the Yanomami, who engage with them mainly through clientelistic exchanges of goods and salaries for votes. There is little doubt that this political party model was lingering in the Yanomami's initial understandings about an indigenous organization. Since the creation of Horonami, these same Yanomami have been involved in struggles for a demarcated territory and a better health system. A clear-cut differentiation is being made between « politics » - associated with obtaining things from the government and « organization » - linked to defending rights and defined in opposition to « politics ». Moreover, we have seen « things » can metaphorize a wide range of requests. My colleagues insist that what was being asked from Hutukara were explanations, not things or money. This does not mean that Parima Yanomami are not interested in manufactured goods, nor that the entanglement between indigenous and party politics has been resolved. What I am saying is that it is misleading to read the connection between « organization » and manufactured goods as the latter being the sole expected outcome of the former.

\section{Improvisation}

Wayamou dialogues contain a range of blends of conventionalized and improvised metaphors, phrases and rhetorical devices (e.g. contrastive comparison, antiphrasis, synecdoche). Young participants repeat stereotypical formulas, whilst elders mix more or less metaphorical statements in creative sequences adjusting for the occasion. I dwell on improvisation for two reasons: 1. it is clear from my conversations that Yanomami consider this inventiveness key to being aka hayu and thus to performing well in wayamou; 2. the improvisatory and metaphorical character of wayamou are both important features of Yanomami shamanism, clearly of the horizontal type in Hugh-Jones' (1994) terms. The connection is not lost on the Yanomami, who, as we worked, commented on how those who excel in wayamou « speak like shamans », meaning they can talk knowledgeably about all sorts of things, mundane or obscure, passing from one subject to the other seamlessly. 
The following segment from Marcelo's wayamou is a good example of metaphorical flair and careful choice of words. Pursuing the main interest of the visitors to the assembly, Marcelo metaphorizes the request for explanations about Whites' financial assistance through the figure of a woman whom Kopenawa has obtained in marriage from Whites of Caracas. ${ }^{7}$ In this context Marcelo again impersonates what he wants to hear from his hosts:

1. ai prowëhëwë a pufi hatukëwëweini

Some elder (lucid, knowledgeable person among the hosts)

2. " hai! kamiyëni ya nowã ta tha sho »

[Will say] « hai! I will explain [about Hutukara] at once»

3. "awei, fei suwë a rë ipirefe »

«Yes, that [white Caracas] woman [Kopenawa] has taken/married»

4. «ai shomi shamathari wamakini »

« you (second-person plural) Shamath ari from another community/unknown to us »

5. « ëyëmi yãrimona wama hiki kãi fa kuaaimani »

« you have come here with yãrimona hiki love magic substance »

6. «napë wama thou fa yã̃ koropoimanì » ${ }^{8}$

« you have approached us carrying Whites' love magic (perfume)»

7. " eha a fiõkasi niya ta yãriyohe »

« here they will cover the women's nose and mouth (with the love magic)»

8. " ya e niya kuu ma mrãõ tëhë ma kui »

« even though I was not thinking of saying this »

9. « ei wa e itëtëtou waikia ha »

« given that you have already approached us [host community/Hutukara]»

7. Marcelo explained that had he known more of Brazil he would have mentioned its capital.

8. This translation requires additional commentary. The expression yã̃ koropoima- refers to the specific way this love magic/perfume is carried by the approaching Yanomami. It was explained to me as a person carrying a small stick with a cloth or cotton tied to one end, which has been soaked in the perfume contained in a bottle. The decomposition of $y \tilde{a} \tilde{\imath}$ (tie) koro (bottom) -po- (hold) -ima- (approach) conveys this information, whereas napë $t^{h} \mathrm{Ou}$ is the referred bottle of perfume. 
10. « mori a ta wamoru, mori, mori, mori, mori, mori »

«make love to one, [only] one, one, one, one »

\section{1. nowã niya thamou kë yaro, ei kë ya, ei, ei, ei}

Because you will inform us [about Hutukara], here I am, here you have me (ready to listen)

The general idea of this sequence is that the Parima visitors have come with friendly intentions to learn about Hutukara in order to create an organization themselves. The woman referred in line 3 is a Caracas woman who stands for Whites' aid. Line 4 refers to the fact that the Parima visitors are strange to their hosts at the assembly. Lines 5 and 6 mention the visitors have come, first with yãrimona hiki love magic (5) and then with perfume (6), which is assimilated to a kind of Whites' love magic for both substances seek to attract women. Line 7 refers to the way such love magic is applied to reluctant women. From 8 to 10 the imagined elder says he will indeed explain about Hutukara. Making love to the woman in line 10 is a metaphor for the explanation. Line 11 states this is what Marcelo wants to be informed about.

All this is « alliance talk » among people who consider each other shomi « different, other » and who would not normally visit each other. Indigenous politics has brought them together in the assembly. Marcelo thus evokes both their status as mutual strangers and the visitors' desire to help each other out. Several subtleties in his words convey this context. It is assumed that Hutukara has not gained the favor of Whites easily and hence the Caracas woman has been obtained by force (ipi-). Whites normally don't care for Yanomami and their aid doesn't come about without a lot of convincing. In the same way, visitors' recourse to love magic to obtain a reluctant women (the advice and mediation with Whites they expect from Hutukara) conveys the sense that, just as Whites' aid has not come easy to Kopenawa, neither will it be effortless for the visitors to obtain the favor of their hosts. The impersonated host who changes his mind and accepts to provide the sought explanation reiterates the hope that friendship struck during the assembly will persuade the hosts into offering advice. Finally, this host's insistence on making love only to one woman indicates the visitors are not after Hutukara's money, just their advice. So whereas the demand of a woman may be a conventionalized metaphor, Marcelo's choice of words couches the demand carefully, displaying heightened awareness to context.

The following fragment shows how metaphorical sequences are not just embellishing devices, but ways of evoking deep signification, which requires knowledge of history, myth and cosmology.

\section{1. fei Surucucus thë rë praope}

The community/people of Surucucus (a Yanomami region in Brazil, east of Parima) 


\section{2. fei sipara watanamo rë tape}

those long machetes like the fruits of the watanamo $^{9}$ tree that abound there

3. weti ipa a ma rapahawë ma mrai

give me one, it doesn't matter if it is only a short one

4. weti ipa a ta pufio

give me mine

\section{5. kihi shokekere thë pariki paimi rë praorati}

On the thick [with fern] flanks of the Shokekere mountain that lies afar (in Parima)

6. moromoroma ya pë pafetimape

I will slash the ferns (to make a garden)

7. ipa a ta yefimapa

place [my machete] on my back

These lines were explained as follows:

ipa organización ya thaprai mi fetuopë. Organización fikari a ... Moromoroma ya ki fa hoyarini, ya iyai kãi toprao përiopë. Organización thë ã thai ha, organización $t^{h} \ddot{e}$ a nakai ha.

I will make my organization on my part [when we go back to Parima]. An organization is like a food garden. Having cleared the ferns, I can live well eating plenty. He [Marcelo] is talking about the organization, he is asking for/about it.

The connection struck between an indigenous organization and a food garden is not a capricious trope. The ferns mentioned are part of Parima people's strife. Having replaced the forest in much of the surrounding hills, it has left the Yanomami with no nearby fertile grounds. The ferns thus epitomize hunger. That an organization can supplant the ferns with food gardens is a powerful trope: it is the food that can put an end to hunger. Moreover, on several occasions and in several places, I have heard Yanomami equate gardens with what Whites work for (money, salaries). At some level of analogy it is an inter-cultural metaphor for what sustains wellbeing.

A final form of witty improvisation key to aka hayu-ness is the introduction of slight variations in the responses to the interlocutor in the lead. An experienced speaker improvises variations in several ways: changing locative suffixes; introducing synonyms; emphasizing the lead's phrase with an added word or

9. I was told this tree has pods like those of the krepõ tree (Guama in local Spanish, inga edulis [Lizot 2004, p. 176]), only longer. The metaphor hinges on the length of the pods. 
morpheme; commenting on the lead's phrase; sometimes simply acknowledging what the lead has said. A short example suffices to illustrate the subtlety of these variations.

Lead

Response

1. ha, pithariwë ikaprarotihe

Spirit of the ground/earth: don't begin laughing

2. pithariwë a kafiki ta humiparu

Spirit of the ground/earth: keep your mouth shut

Lines 1 and 2 are addressed to Pithariwë, a demon associated with the ground who causes disease. They are invocations for him not to pay attention to the Yanomami. Avoiding his interest is a way of keeping disease at a distance. It is implicit that if he laughs it is because he is capturing or devouring human souls. Note the change from « begin laughing » to « keep your mouth shut ».

3. Ha, amoa kë a ta yuru

Retain the/my chant

4. amoa ã wã shinõ ta tëri Always/only retain the/my chant

In line 4, the response is a synonym: $w \tilde{a} t \ddot{e}-=w \tilde{a} y u-$. Both mean to « retain chants » or formulas of wayamou discourse (Lizot 2004, p. 472, 478). "Shinõ », meaning « always » or « only », adds emphasis. « Chants » refer more generally to what is being said in the wayamou.

\section{$[\ldots]^{10}$}

10. ha, titiriwë ikatiho

Spirit of the night: do not laugh

11. titiriwë a rë kui a ikaprarotihe Spirit of the night (and not any other): don't begin laughing

From 10 to 11, there are two modifications: a rë kui is a way of particularizing « this one, as opposed to any other ». Next, the infix -praro- is added to ikatihe

10. Lines 5-9 are missing in this extract. 
(laugh, prohibitive), which becomes the prohibitive of « begin laughing 》 (see Lizot 2004, p. 328). Titiriwe is the spirit of the night, another demon intent on capturing human souls. As in lines 1 and 2, the objective is to keep disease at a distance.

12. Ha, ei henaki rë kui o

These flowers (not any other)

13. ei henaki rë kui

These flowers (not any other)

There is no change from 12 to 13 . Henaki is a contraction of kõe henaki, a plant whose flowers women use as ear adornments (Lizot 2004, p. 169). It is a metaphor for women.

14. ha, henakt ikaprarotihe

Flowers: don't begin laughing

15. henaki kasi wateatihe

Flowers: don't smile

From 14 to 15 , « smile » kasi wate-, replaces « laugh »ika-.

16. ha, hei yuri a rë huoyahi

The fish that live nearby

17. fei a pata parimi rë fuope Those who live forever (in the water)

From 16 to 17 there are several variations. Parimi refers to things eternal, and in this context means that fish live on as long as there is water. Pata is added as an intensifier. The locative suffix $-y a h i$, to be in front of, or near, the place of enunciation (Lizot 2004, p. 489), is replaced by the locative -pe, which in this context refers to something taking place « near or below the water, below the ground, in a burrow » (ibid., p. 308).

18. ha, ei a totori rë yërëawei

The turtle stays still (crouched on the ground)

19. ei a tikukuprou mrai, ei a yërëo rë kõõpe

That one doesn't go to live elsewhere, it [will be] there again, still/it is always there, still (crouched on the ground) 
Lines 18 and 19 refer to the stillness of the turtle. Yërë- in this context refers to being in a crouched position on the ground (ibid., p. 506). Marcelo reinforces its stillness by saying it will not go to live elsewhere.

Even this briefest of samples is enough to realize the ability involved in quickly introducing variation in one's response. It is this variation that testifies to the skill and wit of aka hayu performers. This appreciation sheds some doubt as to the adequacy of a clear-cut distinction between semantic and non-semantic utterances of the « back channel » type, such as Urban (1986) adopts in his analysis of South American ceremonial dialogues (see Monod Becquelin and Erikson 2000, p. 16). To be sure, responses like those presented add little in semantic terms, but for the Yanomami these slight alterations are what counts, « metacommunicatively » conveying aka hayu skill. Furthermore, the wit in responding not only evidences that one has understood the lead's words (as in back-channel « yes » or « that's it » or simple repetition of the lead's statement), but it also shows that one has correctly inferred an often oblique insinuation - about a mythical event, a distant place, a spirit's habits - and, when uttered as a challenge, it additionally demonstrates one's knowledge on the matter.

\section{Personal pronouns, kin terms and gender shifting}

The last two features that are dense in wayamou are the common gender and personal pronoun shifting. There are two reasons for this examination. On the one hand, I propose that the use of kin vocatives and gender shifting are means of indexing the status of visitor-host relations or effecting their transformation. This is a novel explanation of this notable feature of wayamou, and one that situates this phenomenon alongside other tropic devices drawn upon to achieve desired political outcomes. On the other hand, speakers in wayamou occupy multiple enunciative positions, another feature reminiscent of Yanomami and other forms of shamanism that further illustrates the proximity between political and shamanic discourse.

Kin terms such as « my brother-in-law » and « my father-in-law » are often substituted by «my wife » and «my mother-in-law », respectively. Equally, «I » may be substituted by « he/him » and « you » by « you two (dual)» or « you (plural)». What do these shifts achieve? Lizot (1994b, p. 60-61) suggests they are means to distance the speaker from his addressee, avoiding a direct and too frontal address. This is in accordance with what I was told about certain kin usages in non-ritual circumstances. For example, it is inappropriate to address your father-in-law as such, shoape; instead, one must say pata « elder same-sex relative », leaving the relation wawëtoimi, « unclear ». So if in general Yanomami manipulate personal pronoun use to avoid directness, it is expectable for the delicate circumstances that call for the wayamou to require augmented care with such diplomatic devices. 
It is also true that a wayamou participant is often not just speaking his mind but also stating a collective position, in which case substitutions of the first-person singular for the dual or plural could be related to representativity. Likewise the use of the third person in self-reference may pursue the detachment of impersonal expressions (see Lizot 2000, p. 172). Finally, a speaker may address specific people in the audience, a specific category of people or all those present. In these latter cases, pronouns used cannot be considered substitutions, for what is at stake is a shift of addressee.

Alès (2006, p. 268-273), on her part, analyzes gender inversion in wayamou together with its occurrence in shamanic curing. Both wayamou and shamanic performances are imbued with inverted contexts, articulating important oppositions: day and night, living and dead, in the first case; human and spirit worlds, in the second. In Alès' view, gender inversion is of a kind with the general tropic environment of wayamou and participates in its ritual efficacy by way of transforming ordinary language. Whilst I fully concur with her analytical approximation of features of wayamou and shamanic discourse and her attention to trope and ritual efficacy, I want to suggest gender shifting and vocative kin term use do more than signal ritual, or draw heightened attention to a particular context of intra-human or inter-specific politics.

A more comprehensive understanding of gender shifting and the use of specific vocatives in wayamou requires a brief examination of their use in normal circumstances. Vocative kin terms, as opposed to terms of reference, are extremely varied because they can carry overtones of estrangement or endearment, contributing to the performance of « affinal civility », to borrow from Basso (2000). From a thorough conversation on the subject with one of my Yanomami colleagues it can be said that appropriate vocatives change mainly according to social distance and age.

For example, among co-residents, the use of shori or heriyë (brother-in-law) is estranging, the term being more appropriate for outsiders one is not well acquainted with. Terms for a co-resident brother-in-law include suwëpiyë (my wife), ama (sister-in-law), ou (wë) (brother-in-law friendly), wariti (lit.: ugly) and yai $t^{\text {h }} a$ (lit: strange, different). The latter two terms appear to be playful inversions, joking affinal terms that connote proximity or affection. These terms are nofimou $t^{\mathrm{h}} \ddot{e} \tilde{a}$ 《 amicable terms » and also pata $t^{\mathrm{h}} \ddot{e} \tilde{a}$ 《 elder's talk ».

Combining these comments with Alès' (2006) analysis, it can be said that affinal kin terms of address among same-generation or elder co-residents are inappropriate and hence are diluted with more generic terms (shoape $\rightarrow$ pata) or replaced with either « friendly affinal terms », terms involving gender shifting or joking expressions. Shoape, shori, heriyë, fekamayë, prahawë thë ã, yafit ${ }^{e}$ rimi pë riha wa kuimi, thë hirimamou kirihiwë. " Father-in-law, brotherin-law, son-in-law, are terms that distance, you don't use them among coresidents, it sounds shameful. » Among youngsters, more direct vocatives are 
unproblematic. So whilst youngsters and outsiders are addressed more directly, elder co-residents play with the options just mentioned. It follows that the use of different vocatives indexes the state of a relation or the tone one wishes to convey in addressing someone.

In the wayamou sessions I transcribed, the most common substitution is that of brother-in-law for wife. Pursuing the issue, it was clear that the use of « wife» for «brother-in-law» is considered nofimou $t^{\mathrm{h}} \ddot{e} \tilde{a}$ 《 friendly talk» or $t^{\mathrm{h}} \ddot{e} \tilde{a}$ okewë « harmless talk », whilst the use of shori « brother-in-law» is not. Moreover, to an extent, this use is an invocation of conjugal harmony. Ipa suwëpiyë ya ahetepou rë kurenaha thë kua yaro, suwëpiyë ya kuu. « Because I regard him [interlocutor] in the same way in which I am close to my wife, I say "my wife". » Another common term for brother-in-law was ama, or amawë, which Alès considers a term of address between sisters-in-law, and yet I was told it was used between (real) sisters-in-law and (real) brothers-in-law. Following Alès, I am led to conclude that ama is primarily used among sisters-in-law and secondarily may be used among brothers-in-law. Without discounting this order of primacy, it essentially signifies same-sex, same-generation affinity. This is what I could tell from my discussions, and is in accordance with Alès' analysis for the term ote, which in her analysis is a close - though not identical - equivalent of ama (ibid., p. 265). Ama appears to connote proximity or affection among sisters-in-law and brother-in-law alike, as Alès points out in relation to ote, a usage attuned to the companionship typical among same-sex, same-generation affines (ibid., p. 265-266).

If this analysis is correct, the use of ama (sister-in-law) alongside suwëpiyë (my wife) in wayamou are almost equivalent means to connote amicable intentions through a gender shift that evokes the conviviality of long-term co-residence. Amawë, okewë thë ã, hawe yafitherimi, a yafitherimi mrai ma kui. "Amawë is harmless talk, as if [your interlocutor] were a co-resident, even though he is not. »

More generally, it can be said that wayamou dialogues intent on strengthening ties may be more prone to these substitutions than those where people are treating each other as shomi « strangers », where the terms for brother-in-law, such as shori, shoriwë and heriyë, index this social distance. In a more conflictive context, terms for brother-in-law are dropped in favor of more insulting expressions: « coward », " incestuous », and the like. Even this incomplete examination is enough to suggest that wayamou incorporates the meaning and function of different vocatives and gender shifts used in quotidian circumstances to index the state of visitor-host relations or stimulate their transformation.

In a different context, the use of a given kinship vocative is integral to a metaphorical situation that has been set up, or is otherwise linked to the context of the discourse. For example, when Marcelo is requesting to be informed about Hutukara, at one point he metaphorically demands a woman from his hosts (see above). In that context, he addresses an imagined host as shoape 
" father-in-law », and uses fekamayë « my son-in-law » as the vocative the impersonated host should use to address him. Later in the same discourse, he addresses the audience: " Elder brothers, shaman elder brothers, listen! » He then switches to impersonating their thoughts: « This is what my younger brother is saying. " Appealing to be heard, Marcelo puts himself in the position of a younger brother of his hosts.

A final ingredient of wayamou's pronominal play involves de-centering or perspectival linguistic techniques. We have already seen how interlocutors put words in each other's mouths as a form of requesting a particular regard for themselves. Whilst reported speech is characteristic of the Yanomami language, our examples refer to desired responses - « not yet reportable speech », as it were. Note that this form of citation is not an attempt to draw on the authority of mythical, historical or other forms of «traditional » discourse reframed in a contemporary political context, as Parmentier (1994) shows to be the case in the Belauan case he analyzes. This is more a matter of impinging on the interlocutor's disposition by way of (semantically) anticipating what one hopes to (pragmatically) effect.

There are other teknonymic ways of self-reference, such as referring to oneself as suwëpifë (your wife) or amafë (your sister-in-law, your affine). In more conflictive contexts, where the assimilation of warfare to hunting is common, a speaker may position himself as an enemy's potential predator or prey using ira (jaguar) or yarohe (your game) as self-reference (Lizot 2000, p. 176, 173).

In the variety of ways we have just examined, taking the other's point of view seems to be a way of impinging on his thoughts: impelling interlocutors to accede to one's demands evoking an imaginary kinship tie, a prospective response or the gravity of possible conflict through images of predation. In short, speakers enunciate from a multiplicity of kin and pronominal positions and switch addressees to different relationship-engendering effect.

Whereas some tactics seem to « neutralize the self » (Franchetto 2000, p. 483), and deflect directness, at other moments the self is forcefully reinstated: « Thus I speak! » In addressing the interlocutor, similar switches from deflecting to focusing statements are recurrent; people in the audience are addressed collectively, partially or individually. Exchange items merely alluded to in poetic fashion are then vehemently demanded: " Give me mine! » All I can say is that, some times the pronominal environment eludes the self and the other, obviating the directness of the face-to-face setting, at other moments, interlocutors situate themselves back in the « you » and «I $\mathrm{I}$ ) of their one-to-one interaction. A similar play between circumvention and directness holds if we consider how the metaphorical content of the dialogue is cast through very potent vocal expression. With such an oscillating relation involving diffusion and focus, circumlocution and directness, it is not possible to characterize wayamou in terms of a fixed or characteristic relation between speakers and the content of their speech, a 
relationship that students of speaking have shown to be analytically important when considering verbal arts in political discourse (Stasch 2011).

At this point we can also review a number of ways in which trope is performatively used to influence and persuade: oblique references to a historical and mythical past; imaginary situations set up to stage others' responses; de-centering pronoun shifts to skirt overly direct expression; kinship manipulations and gender shifts to invoke appropriate relationship contexts; tangential evocations of desired objects; mobile enunciative positions. In line with Chernela's (2001) analysis of a Wanano ritual dialogue as a performative event as a whole, we could say wayamou's performative character is achieved by myriad component performative utterances, repeated and diverse attempts to impinge on interlocutors/opponents that return an evaluation of one's efficacy in driving the relationship in a desired direction.

\section{Conclusion}

I shall conclude in two steps. First, I shall recapitulate the ground we have covered in our description of the « total social fact » of wayamou, with an aim to hone my argument that expert wayamou discourse exhibits a particular aesthetics of political agency, one that it shares with shamanism. Having done so, I shall next show how this invites us to rethink longstanding distinctions within the political anthropology of Lowland South America between headman and shaman, political and religious influence, and inter-specific and intra-human relations.

Expert (aka hayu) discourse is metaphorical (ã wã poapou), forceful and effective in transforming conflictive relations into peaceful ones - the passage from dangerous/angry (wayu) to calm (oke-) affective states. Here we already have an indication of aka hayu discourse in wayamou having a specific aesthetic, semantically metaphorical and pragmatically forceful, which is the form of political efficacy.

Next, we saw how naming the forest, urifi ã wëyët, one of the indispensable features of wayamou, has the capacity to index exchange expectations and past events so as to bear on the specifics of the visitor-host relation. Let us recall that Yanomami have a strict prohibition on naming the dead, and, to a lesser extent, on personal names. Uttering one or the other is an invitation to conflict. I think the necessity of allegoric, circumventing words in this context of wayamou discourse is of a kind with these avoidances: their efficacy to resolve conflict hinges on a delicate artistry that must compensate for the danger of exposing people to saying and hearing things that, if peace is to be sustained, might best remain unrecalled. Here metaphor works mainly through diplomatic indirection, an aspect of much verbal art and situations of conflict (Brenneis 1987, 1988), but more interestingly recalls the care with words in the Yaminahua shaman's 
description of his chants, where « twisted language brings me close but not too close... with normal words I would crash into things » (Townsley 1993, p. 460).

Naming the forest along with other wayamou procedures also give cues as to knowledge (of distant places, mythical events, cosmological planes) and skills (eloquence and virtuosity) acquired in dreams. My impression is that with these displays of knowledge and skill, and with the strength with which they are uttered, a speaker earns for himself the acceptance of his interlocutor/ opponent. Wayamou participants each have a worth that may only be overcome in its recognition, such is the work of an artful performance. At issue is a measuring up of regards. In this case metaphor participates in indexing the high-valued, and eminently shamanic, ability to « dream afar » and recalls the role of verbal arts in persuasive oratory (Caton 1987) and so many forms of « crooked » or « veiled speech » in achieving social and political influence (see Rosaldo 1973; Strathern 1975).

Finally, we have seen that improvisation, a valued requisite for aka hayu-ness and characteristic of Yanomami horizontal shamanism (Hugh-Jones 1994), takes several forms: the ability to talk knowledgeably about anything, seamlessly switching from one theme to another; witty enchainment of meaningful multilayered metaphorical sequences; and quick alterations to lead phrases in the speaker's responses. The multiplicity of enunciative positions speakers adopt in wayamou also place it well within the discursive register of shamanism.

Considering the set of features of aka hayu discourse, I think we have a case for suggesting a. that it is a chief means of influencing others, that is, an aesthetics of political agency; and b. that circumlocution/indirection seems to be particularly relevant to this aesthetics. Considering other ethnographic reports that stress the importance of indirection as a mode of appropriate relating in diverse political, ritual and everyday contexts (see Graham 1993 for the Xavante, and Schuler Zea 2010 for the Waiwai), a more systematic investigation into indirection in diverse contexts beyond those of language would appear to be a profitable line of inquiry for Amazonian political anthropology. I think we also have a case for suggesting $\mathrm{c}$. that this aesthetics shares with shamanism many of the discursive devices and a knowledge practice (dreaming afar) at the base of its efficacy. Let us not forget how in many of the metaphors deployed in the Hutukara wayamou sessions (2010 and 2012) what we find are Yanomami signifiers pointing to non-Yanomami signifieds: a woman in marriage stands for financial aid; love magic is assimilated to Whites' perfume; a falcon-spirit that blows magic substances over a powerful man in Caracas stands for a request made to Hutukara, soliciting they intercede on behalf of their Venezuelan counterparts with President Chávez, thus predisposing him to being generous when Horonami representatives meet him subsequently (see Kelly 2015). Wayamou can metaphorically account for any aspect of inter-ethnic politics or 
the non-indigenous world. As a political device it is primarily a form that, like shamans themselves, can engage with any content, however foreign.

$$
* * *
$$

At least since Clastres and Lowie, the role of oratory in Amerindian politics has been acknowledged and developed. One such development was to question whether it was chiefs/headmen - powerless owners of a word without audience or shamans - controlling symbolic life-giving and life-taking resources - who really possessed the political means to exert collective influence (Descola 1988). Descola rightly queries whether we should not consider shamans' power « political ». Not in Clastres' terms, he says, but

Oui si on pense que la faculté d'apparaître comme la condition de la reproduction harmonieuse de la société est une composante fondamentale du pouvoir dans toutes les sociétés prémodernes. (Ibid., p. 825)

Considering the political aesthetics involved in wayamou's efficacy, can we not flip Descola's query round and ask whether the political is not also shamanic? Is it not up to aka hayu men to mend exchange relations and secure alliances? Is it not the knowledge and skills derived from dreams and displayed in wayamou that is put to the service of harmonious inter-community relations? Are we not faced with a horizontal shaman-like personage?

Following Descola's lead, part of the discussion about power in Lowland South America shifted from the realm of politics to that of religion, where, to the political role of shamans, that of the more priest-like prophet was added (Hugh-Jones 1994; Santos-Granero 1993; Stuztman 2005). In this latter religious sphere, the power of words uttered in metaphorical language comes into view as a key ingredient of shamanic efficacy in all its curing, " world creating 》 and transformative capacity (e.g. Townsley 1993; Overing 1990; Cesarino 2015).

What is striking about elders' aka hayu discourse is that it brings to the political sphere the metaphorical efficacy we are used to seeing mainly in shamanic discourse. If we can think of metaphor/circumvention as an aesthetics of political agency, this can breach the gap between anthropological analysis of inter-specific relations and intra-human ones.

First, if the mark of inter-specific agency is the reversal of a perspective or subject position (see Viveiros de Castro 1998), is this not what aka hayu discourse does? Impinge on and, if successful, revert initially distinct positions? Align peoples' disparately oriented minds to « live well » among allies? Imbricated with dream knowledge, metaphorical agency and the regulation of social organization, is aka hayu discourse not a form of shamanism?

Second, if we consider the perspectival play that proliferates in wayamou, we are reminded of, for example, the Araweté shaman's chants that Viveiros de Castro (1992, p. 226-248) describes, mentioning its metaphorical content, 
multiple enunciative positions, dialogic character, emphasis on originality and, ultimately, insertion in the exchange of life and death sustained between humans and gods. The device of adopting the other's point of view is as recurrent in Arawete shamans' and killers' songs, as it is in wayamou. This comparison serves to reiterate my point that wayamou deploys in the intra-human sphere a number of metaphorical and deictic devices that have become commonplace in the analysis of inter-specific shamanic negotiation. In a sense, in wayamou, human others are treated in the same way as spirits, which, on the one hand, suggests the anthropologically acknowledged continuity between humans and non-humans when considering their position as Others, and, on the other, suggests a much less perceived use of a common political aesthetics across ontological boundaries. ${ }^{11}$

$$
* * *
$$

Two brief excerpts from Davi Kopenawa's auto-ethnographic tour-de-force offer insights as to the connection between verbal aesthetics and political efficacy. On the wayamou and yãimou, Kopenawa says they are "le cour de notre parler » (Kopenawa and Albert 2010, p. 398), and continues:

Lorsque nous disons les choses seulement avec la bouche, durant le jour, nous ne nous comprenons pas vraiment. Nous écoutons bien le son des paroles que l'on nous adresse, mais nous les oublions avec facilité. En revanche, durant la nuit, les paroles $d u$ wayamu et $d u$ yãimou s'accumulent et pénètrent profondément dans notre pensée. Elles se révèlent dans toute leur clarté et peuvent être véritablement entendues. (Ibid.)

It is telling that such a trope-ful form of language is what Yanomami use to reveal the " clarity of words » and make themselves understood. Further on:

Si [les] [Whites'] anciens [des Blancs] connaissaient le parler de nos dialogues yãimu, je pourrais leur dire véritablement ma pensée. Accroupis l'un en face de l'autre, nous nous disputerions longuement en nous frappant les flancs. Ma langue serait plus habile que la leur et je leur parlerais avec un telle vigueur qu'ils en seraient épuisés. Je finirais ainsi par empêtrer leurs paroles d'hostilité! Malheureusement, les Blancs ignorent tout de nos manières de dialoguer. (Ibid., p. 414)

Whites are without doubt the mightiest of enemies and stubborn minds to change, if only Yanomami could dialogue with them in their terms ... *

* Manuscrit reçu en avril 2016, accepté pour publication en octobre 2016.

11. A similar point is made by Ramo y Affonso (2014) when comparing Guarani (mbya) inter-specific politics and those that they undertake with Whites. The author's political reading of a people known in the literature for their religiosity is also suggestive of the appropriateness of looking for analytical threads between inter- and intra-specific politics, and hence religion and politics, in Amazonianist anthropology. 
On Yanomami ceremonial dialogues

\section{References cited}

Albert Bruce

1985 Temps du sang, temps de cendres. Représentation de la maladie, système rituel et espace politique chez les Yanomami du sud-est (Amazonie brésilienne), Ph.D. thesis, Université de Paris X.

ALÈs Catherine

1990 «Entre cris e chuchotements: représentations de la voix chez les Yanomami », in Catherine Alès (ed.), L'Esprit des voix. Études sur la function vocale, $\mathrm{La}$ Pensée Sauvage, Grenoble, p. 221-245.

2003 «Función simbólica y organización social. Discursos rituales y política entre los Yanomami », in Catherine Alès and Jean Chiappino (eds.), Caminos cruzados: ensayos en antropologia social, etnoecología y etnoeducación, IRD Editions/ULA-GRIAL, Merida, p. 197-240.

2006 «L'aigle et le chien sylvestre: distinction de sexe dans les rites et la parenté yanomami », in Catherine Alès (ed.), Yanomami l'ire et le désir, Éditions Karthala, Paris, p. 241-280.

BAsso Ellen

2000 « Dialogues and body techniques in Kalapalo affinal civility », in Aurore Monod Becquelin and Philippe Erikson (eds.), Les rituels du dialogue, Société d'ethnologie, Nanterre, p. 183-198.

Borges Marcelo, Alfredo Silva and Donaldo Silva

2015 Yãnomãmi Horonami theri yamaki rë kui, Brasil thë urifi hami yamaki wayamou rë kuanowei thë ã, Horonami/Wataniba, Lima.

BRENNEIS Donald

1987 « Talk and transformation », Man, 22 (3), p. 499-510.

1988 «Language and disputing », Annual Reviews of Anthropology, 17, p. 221-237.

CARneiro da Cunha Manuela

1998 « Pontos de vista sobre a floresta amazônica: xamanismo e tradução », Mana, 4 (1), p. 7-22.

CARrera Javier

2004 The fertility of words: aspects of language and sociality among Yanomami people of Venezuela, Ph.D. thesis, University of St. Andrews.

Caton Steven

1987 «Power, persuasion, and language: a critique of the segmentary model in the Middle East », International Journal of Middle East Studies, 19 (1), p. 77-102.

Cesarino Pedro

2015 « Montagem e formação do mundo nas artes verbais maruno », Species Revista de Antropologia Especulativa, 1, p. 66-78.

Chernela Janet

2001 «Piercing distinctions. Making and remaking the social contract in the NorthWest Amazon », in Laura M. Rival and Neil L. Whitehead (eds.), Beyond the visible and the material. The Amerindianization of society in the work of Peter Rivière, Oxford University Press, Oxford, p. 177-195. 
Cocco Luis

1972 Iyëwei-teri. Quince años entre los Yanomami, Escuela técnica popular Don Bosco, Caracas.

Descola Philippe

1988 «La chefferie amérindienne dans l'anthropologie politique », Revue française de science politique, 38, p. 818-827.

1996 The spears of twilight: life and death in the Amazon jungle, J. Lloyd (trans.), The New Press, New York.

EIBEL-EISESFELDT Irenaus

1971 «Eine ethologish interpretation des Palmfruchfest des Waika (Venezuela) nebst einegen Bemerkungen uber die bindende Funktion von Zwieggesprachen », Anthropos, 66, p. 767-778.

ERIKSON Philippe

2000 «Dialogues à vif... Note sur les salutations en Amazonie », in Aurore Monod Becquelin and Philippe Erikson (eds.), Les rituels du dialogue, Société d'ethnologie, Nanterre, p. 115-138.

Fock Niels

1963 Waiwai: religion and society of an Amazonian tribe, The National Museum (Ethnographic series, 8), Copenhagen.

FRANCHETTO Bruna

2000 «Rencontres rituelles dans le Haut-Xingu : la parole du chef », in Aurore Monod Becquelin and Philippe Erikson (eds.), Les rituels du dialogue, Société d'ethnologie, Nanterre, p. 481-509.

GNERRE Maurizio

1986 «The decline of dialogue: ceremonial and mythological discourse among the Shuar and Achuar of Eastern Ecuador », in Joel Sherzer and Greg Urban (eds.), Native South American discourse, Mouton de Gruyter, Berlin/New York/ Amsterdam, p. 307-342.

GRAHAM Laura

1993 «A public sphere in Amazonia? The depersonalized collaborative construction of discourse in Xavante », American Ethnologist, 20 (4), p. 717-741.

Hugh-Jones Stephen

1994 «Shamans, prophets, priests and pastors », in Nicholas Thomas and Caroline Humphrey (eds.), Shamanism, history, and the state, University of Michigan Press, Ann Arbor.

Kelly José Antonio

2011 State healthcare and Yanomami transformations, Arizona University Press, Tucson.

2015 «Aprendendo sobre os diálogos cerimoniais Yanomami », Species Revista de Antropologia Especulativa, 1, p. 45-65.

Kopenawa Davi and Bruce Albert

2010 La chute du ciel : paroles d'un chaman yanomami, Plon, Paris.

Lizot Jaques

1994a « Words in the night. The ceremonial dialogue, one expression of peaceful relationship among the Yanomami », in Leslie Sponsel and Thomas Gregor (eds.), 
The anthropology of peace and nonviolence, Lynne Rienner Publishers, London, p. 213-240.

1994b «Palabras en la noche. El diálogo ceremonial, una expresión de la relaciones pacíficas entre los Yanomami », La Iglesia en Amazonas, 53, p. 54-82.

2000 « De l'interprétation des dialogues », in Aurore Monod Becquelin and Philippe Erikson (eds.), Les rituels du dialogue, Société d'ethnologie, Nanterre, p. 165-182.

2004 Dicionario enciclopédico de la lengua yãnomãmi, Vicariato Apostólico de Puerto Ayacucho, Puerto Ayacucho.

Lizot Jaques and Hélène Clastres

1978 «La part du feu : rites et discours de la mort chez les Yanomami », Libre, 3, p. 103-133.

Migliazza Ernest

1972 Yanomama grammar and intelligibility, Ph.D. thesis, University of Indiana. Monod BeCQuelin Aurore and Philippe ERIKSON

2000 «Introduction », in Aurore Monod Becquelin and Philippe Erikson (eds.), Les rituels du dialogue, Société d'ethnologie, Nanterre, p. 11-27.

Overing Joanna

1990 « The shaman as a maker of worlds » Man, 25 (4), p. 602-619.

PARMENTIER Richard

1994 «The political function of reported speech: a Belauan example », in John Lucy (ed.), Reflexive language: reported speech and metapragmatics, Cambridge University Press, Cambridge, p. 261-285.

RAmo y Affonso Ana Maria

2014 De pessoas e palavras entre os Guarani-mbya, Ph.D. thesis, Universidade Federal Fluminese.

Rivière Peter

1971 « The political structure of the Trio Indians as manifested in a system of ceremonial dialogues », in Thomas O. Beidelman (ed.), The translation of culture. Essays to E.E. Evans-Pritchard, Tavistock Publications, London, p. 293-311.

Rosaldo Michelle

1973 «I have nothing to hide: the language of Ilongot oratory », Language in Society, 2 (2), p. 193-223.

SAntos-Granero Fernando

1993 «From prisoner of the group to darling of the gods: an approach to the issue of power in Lowland South America », L'Homme, 126-128, p. 213-230.

Schuler Zea Evelyn

2010 «Por caminhos laterais: modos de relação entre os Waiwai no Norte Amazônico », Antropologia em Primeira Mão, 119, p. 1-21.

SHAPIRO Judith

1972 Sex roles and social structure among the Yanomama Indians of Northern Brazil, Ph.D. thesis, Columbia University.

STASCH Rupert

2011 «Ritual and oratory revisited: the semiotics of effective action », Annual Reviews of Anthropology, 40, p. 159-174. 
STRATHERN Andrew

1975 « Veiled speech in Mount Hagen », in Maurice Bloch (ed.), Political language and oratory in traditional society, Academic Press, New York.

SURRALLÉs Alexandre

2003 «Face to face: meaning, feeling and perception in Amazonian welcoming ceremonies », Journal of the Royal Anthropological Institute, (NS) 9, p. 775-791.

SzTUTMAN Renato

2005 O profeta e o principal: ação politica amerindia e seus personagens, Ph.D. Programa de Pos Graduação em Antropologia Social, Universidade de São Paulo, São Paulo.

TOWNSLEy Graham

1993 "Song Paths: the ways and means of Yaminawa shamanic knowledge ", L'Homme, 126-128, p. 449-468.

URBAN Greg

1986 «Ceremonial dialogues in South America », American Anthropologist, 88 (2), p. 371-386.

Viveiros de CASTRo Eduardo

1992 From the enemy's point of view: humanity and divinity in an Amazonian society, Catherine V. Howard (trans.), University of Chicago Press, Chicago.

1998 "Cosmological deixis and Amerindian perspectivism », Journal of the Royal Anthropological Institute, (NS) 4, p. 469-488.

WAGNER Roy

1972 Habu: the innovation of meaning in Daribi religion, University of Chicago Press, Chicago. 